\title{
JUVENILE JUSTICE: GENESIS AND CURRENT STATE IN UKRAINE
}

\author{
Mariia Kyrylenko* \\ Institute of International Relations, International Law Department of Taras Shevchenko National \\ University of Kyiv, Ukraine, E-mail: marykyrylenko5@gmail.com
}

(Received: September 2020; Accepted: October 2020; Published: November 2020)

\begin{abstract}
In this paper, the problem of the functioning of the juvenile justice as a system of all parts of the state mechanism, that deal with the problems of protection and socializing of children is considered. It is determined that the protection of children's rights in Ukraine is an urgent question. That is why providing proper conditions for life, development and socialization of the younger generation has become one of the priorities for the state policy of Ukraine. Hence, juvenile justice is one of the most effective ways to protect the rights and interests of children and youth. However the tendencies of formation of the juvenile legal policy of the state influence whether legal regulation of children's protection can be implemented in the legal system of the state to that extent that it promotes the development of children's protection. Thus, there is a necessity to analyze the genesis, development and the current state of the juvenile law in Ukraine taking into account the practice of foreign states and defining the further perspectives of the juvenile law.
\end{abstract}

Keywords: juvenile justice, juvenile court, legal minors, criminal offense, the legal status of a child.

\section{Introduction}

Juvenile justice has existed for over 100 years now. The United States of America was a pioneer in this matter when in 1899 the first "children's court" was established in Chicago. Currently, there are several effective models of juvenile justice - English and American, continental, and Scandinavian. As a general rule, they operate on the basis of separate legislative acts on judiciary and procedure in juvenile justice bodies. Thus, in the United States, the example of such acts is the Federal Law on Juvenile Justice and Juvenile Delinquency (1974), in Great Britain - a number of laws concerning the regulation of relations of which children and

\footnotetext{
${ }^{*}$ Corresponding author: Mariia Kyrylenko.E-mail: marykyrylenko5@gmail.com.
} reproduction in any medium, provided the original author and source are credited. 
Kyrylenko, M., (2020)

Juvenile justice: genesis and current state in Ukraine

youth are the parties (implemented since 1908), in Poland - the Law on Juvenile Justice (1982), in Canada - the Juvenile Criminal Justice Act (April 1, 2003).

The functioning of juvenile justice in the world is based on two main models English and Saxon and continental, which are distinguished on the basis of jurisdiction issues. If the juvenile courts of the continental legal system (Germany, France) have broad substantive jurisdiction, the English and Saxon model (Australia, USA) provides limited substantive jurisdiction: the juvenile court considers all types of juvenile offenses, except for serious crimes.

According to the ontological status, juvenile justice can be considered as an exclusive system, which consists of the activities of the state in the realm of juvenile law and institutions that conduct such activities including the state and non-state bodies and forms of activity, that is why it is of the great importance to organize the process in the right way for the effective protection of the rights of legal minors.

\section{The development of juvenile justice in the comparative aspect of different countries.}

The state model of juvenile justice is considered to be the oldest in terms of its origin. It provides the existence of a specialized court that administers juvenile justice, and all other related institutions - state and public - perform ancillary functions. An alternative to the court-centric model is the administrative model of juvenile justice, which operates, in particular, in Scotland, where administrative commissions for juvenile delinquency are central.

In the Scandinavian countries, judicial and administrative juvenile justice are combined. In particular, there are no separate juvenile courts in Sweden, but there is a juvenile judge in a local court or a juvenile division of the court. The leading role among state institutions dealing with the protection of the rights of minors in the Scandinavian countries is played by the social services, organized on a territorial basis, which allows to determine and consider the problem of a particular child by professionals working in the territory effectively, expeditiously and directly.

The foreign experience of involving civil society institutions in juvenile justice is considerably interesting. For example, in the United States, there are non-state juvenile courts in which adults either do not participate at all or only manage the proceedings. These courts hear cases of minor crimes and misdemeanors committed for the first time if the minor has pleaded guilty. Coercive measures used by juvenile courts (attending special classes to overcome drug or alcohol addiction; monetary restitution, obligation to participate in a juvenile court hearing as a juror, etc.) are non-repressive and have significant educational potential.

118 sciendo Journal of Legal Studies Volume 26 Issue 40/2020

ISSN 2457-9017; Online ISSN 2392-7054.

Web: publicatii.uvvg.ro/index.php/jls. Pages $117-124$ 
In New Zealand, there is a practice of holding negotiations between the victim and his or her defenders (relatives) and the juvenile offender and his or her family (or community members). Under the guidance of a mediator, the victim talks about the material and moral damage caused to him, and the offender and his family look for and offer means to compensate for the damage. The agreement reached and concluded between the parties is submitted to the court for approval; if reconciliation is not achieved, the minor's case is subject to trial.

In many countries, such as Sweden and the Netherlands, non-governmental penitentiary institutions for juvenile offenders are effective. Within the local community, a significant part of court decisions in juvenile cases, in particular, public works (minor repairs of buildings, cleaning of the territory, etc.) are executed. In countries where Catholicism is one of the prevailing religions (Spain, Italy, Portugal, Poland), the church plays an important role in juvenile justice.

The conceptual definition of juvenile justice as a system of the state, municipal, and public judicial, law enforcement, and human rights protection bodies, institutions, and organizations that administer juvenile justice with the help of medical, social, and psychological-pedagogical methods deserves attention. This concept also encompasses the protection of rights, freedoms, and interests, as well as resocialization of children in difficult life situations and after being proved guilty of crimes.

The purpose of juvenile justice is threefold: restoration of rights and justifying the reasonable requirements of the victim in accordance with the offended rights; recognition of the damage caused by the offender and assuming responsibility for the elimination of this damage; achieving reconciliation between the victim, the offender and the community in which they live. One of the most effective means of achieving this goal is mediation, which is now implemented in the juvenile justice system of many European countries (Austria, Belgium, Spain, the Netherlands, Germany, Norway, Poland, Slovenia, Finland, France).

Talking about Ukraine, in 2013, alternative bills on mediation were submitted to the Verkhovna Rada of Ukraine, which provide for the child's participation in the mediation procedure, confirming Ukraine's choice of a restorative pluralistic model of juvenile justice and defining the legal basis for implementing and conducting conflict resolution by mutual consent and participation of the mediator.

Putting the things together, the main point of different procedures in the aforementioned states is that any juvenile laws and provisions are effective social mechanisms that allow to restore the physical, psychological and social status of the child and efficiently regulate relations connected with the juvenile crime. 
Kyrylenko, M., (2020)

"Vasile Goldiş" Western University of Arad

Juvenile justice: genesis and current state in Ukraine

\section{The reality of legal juvenile law and legislature in Ukraine}

The choice of the optimal model of juvenile justice for Ukraine was made taking into account the positive experience of more than a century of its existence in different countries.

In Ukraine, there are some legal and organizational prerequisites for the formation of the juvenile justice system, but its judicial element remains the biggest problem that needs to be solved at the legislative level. Some steps in this direction have already been taken. The Decree of the President of Ukraine dated 10.05.2006 № $361 / 2006$ approved the "Concept of improving the judiciary to provide the operation of fair and impartial courts in Ukraine in accordance with European standards". According to the Concept, at one of the stages of reform of the system of courts of general jurisdiction, it is necessary to provide specialization of courts with division into civil, criminal and administrative jurisdiction, providing in terms of such courts a specialization of judges (panels of judges, chambers for consideration of certain categories of cases) for the conduct of pleadings which include a specific element (for example, a subjective element in cases, where minors are the subjects). The concept indicated the need to use the positive experience of democracies in restitution justice, which is based not on the punishment of a person, but rather on reconciliation of the accused and the victim and/or the compensation of material and moral damage to the victim.

The national program "National Action Plan for the Implementation of the UN Convention on the Rights of the Child" for the period up to 2016, approved by the Law of Ukraine dated 05.03.2009 № 1065-VI, provided as one of the tasks that arose before the government to study the possibility of creating a juvenile justice system to improve national legislation in the field of protection of children's rights, develop the mechanisms of preventing children from committing crimes and other offenses and create an effective system of rehabilitation of juvenile offenders.

Today, juvenile justice in Ukraine is organized primarily as one of the elements of the new criminal justice system. Chapter 38 of the Criminal Procedure Code of Ukraine of 13.04.2012 is entitled "Criminal proceedings against legal minors" and in its content generally meets the international legal standards of criminal justice for persons under eighteen years of age. Another step towards the functioning of juvenile justice in Ukraine was the addition to Art. 18 of the Law of Ukraine "On the Judiciary and the Status of Judges", according to which in local courts of general jurisdiction and courts of appeal there is an exact specialization in criminal proceedings against minors, clearly regulated procedure for electing judges who are authorized to carry it out such proceedings and the requirements for them.

On January 19, 2017, the Ukrainian parliament adopted the bill "On Amendments to the Article 4 of the Law of Ukraine "On bodies and services for children and special institutions for children" on improving the legal status of children's 
services", that is one of the necessary regulations for strengthening protection of children in Ukraine. And on February 8, 2017, the President of Ukraine signed the law № 1824-VIII on strengthening state guarantees for the protection of children's rights.

Furthermore, the government has approved a National Strategy for Reforming the Juvenile Justice System until 2023. This is provided by the Order of the Cabinet of Ministers of Ukraine dated December 18, 2018, № 1027-r. The purpose of the Strategy is to provide effective mechanisms in the juvenile justice system, aimed at strengthening the responsibility of the state and society for the protection of the rights of children, increasing the level of social awareness, reducing crime and correction and social rehabilitation of minors in conflict with the law.

It should be noted that the current legal juvenile science in Ukraine is formed taking into consideration foreign experience, the experience of domestic scholars, adoption of strategic plans and concepts in this area, practical implementation of the mechanism of protection of children's rights, searches for new models in legal culture and legal consciousness of the younger generation.

\section{Legal status of the child in Ukraine}

Children still remain the most vulnerable category of members of society. In the conditions of an acute political and economic crisis situation in Ukraine, there is a problem of sufficient provision of the rights of the child in various spheres of social relations: education, medicine, culture. But one of the most significant issues is the criminal law protection of the rights and freedoms of the child. The resolution of this problem requires detailed research not only in terms of the legal regulation of protection but also due to the analysis of the legal status of the child, his rights, freedoms, and interests under both national and international law.

The legal status of the child is regulated by various international and national instruments, namely: the Universal Declaration of Human Rights (1948), the Declaration of the Rights of the Child (1959), the International Covenant on Civil and Political Rights (1966), the International Covenant on Economic, Social and Cultural Rights. 1966), the Convention on the Rights of the Child (1989), the European Convention on the Legal Status of Children Born Out of wedlock (1975), the Family Code of Ukraine, the Civil Code of Ukraine, the Law of Ukraine "On Children Protection", etc.

The legal status of the child is legal opportunities necessary for the full development of a child's personality, which reflects the position of the child in society and his interactions with other subjects of law. By its nature, the legal status of the child is complex, intersectoral, built on the general legal status of the individual. Elements of the legal status of the child, concerning the general concept 
Kyrylenko, M., (2020)

Juvenile justice: genesis and current state in Ukraine

of the legal status of the individual, encompass the principles of the legal status of children, the legal personality of children, citizenship of children, rights, freedoms and responsibilities, guarantees of children's rights, and means and methods of the protection of children in society.

The principles of juvenile law of Ukraine are enshrined in the Constitution, Art. 52 which proclaims the equality of children in their rights, regardless of origin, as well as regardless of whether they were born in or out of wedlock, the prohibition of any violence against a child and exploitation and harassment for such actions, maintenance and upbringing of orphans and children deprived of parental care, at the expense of the state, support, and encouragement of charity for children.

The principles of protection of human rights of children are enshrined in the Laws of Ukraine "On Children Protection" and "On Social Work with Children and Youth", adopted in 2001, as well as in the Law "On Bodies and Services for Children and Special Institutions for Children" etc. Of particular importance for the formation of the legal status of the child is the constitutional and legal status of the individual. In the Constitution of Ukraine, the term "child" is used only in three articles. However, all its rules that determine human and civil rights also apply to children and are very important. Likewise, responsibilities are also an important element of a child's legal status. Certain responsibilities are assigned to a minor when he or she reaches the appropriate age.

Today in Ukraine the main bodies and services for minors and special institutions for social protection and prevention of juvenile delinquency are the Ministry of Family, Youth, and Sports, juvenile services, schools of social rehabilitation, medical and social centers rehabilitation, shelters for minors, criminal police for minors, receivers-distributors, colonies of the State Department of Ukraine for the Execution of Punishments.

But we still cannot say the system of juvenile justice and protection is perfect. And that is why it is one of the obstacles to building a legal, democratic society; because there are various constant violations of the rights of the younger generation. In modern circumstances, when the legal basis for deep social and economic transformations is being laid in Ukraine, the problem of protection of minors acquires a special meaning. There is now a necessity in the awareness of the public and particularly children themselves of children's rights to be protected and the consequences of their violation. However one should remember that the recognition and protection of the rights of the child do not violate the authority of parents and do not reduce the responsibilities of children to the family and society. Statistical indicators of social protection of children in Ukraine prove that the issues of ensuring the normal development of children remain problematic.

There are more than 8 million children under the age of 17 in Ukraine, of which almost $2.6 \%$ are under dispensary supervision. The incidence rate among children 
is 144.0 per 1000 children under 17 years, in particular, the incidence of diseases of the musculoskeletal system is 31.07 per 1000 children. The number of children with disabilities is growing every year in Ukraine. Over the last 10 years, the number of children in Ukraine has decreased by $20 \%$, while the total number of children with disabilities is growing by $0.5 \%$ annually and has already reached $2 \%$ of the total child population of the country. Children with disabilities are often victims of criminals, and their rights due to their peculiarities are more difficult to protect than the rights of ordinary children.

The state policy in the field of child protection should be based on the fact that Ukraine has the highest mortality rate in Europe (15.7 deaths per 1,000 people), the country ranks second in the world in terms of mortality and first in terms of natural population decline (6.3\% or 6.3 people per 1000 inhabitants). The natural decrease was 158.7 thousand, which is 16.3 thousand more than the previous year. These figures prove that the nation is aging, that's why the protection of minors should be of a great priority for the state.

\section{Conclusions}

Taking everything mentioned above into the consideration, the problems of children and adolescents cannot and should not only be the problems of children themselves. These are problems of the whole society and the states and must be solved together. In this matter, juvenile justice is one of the most important mechanisms of protection. It should avoid criminalization of the individual, and promote social rehabilitation and comprehensive socialization of the child. This approach is effective and profitable for the society in which the offender and his rights as an individual are more important than the offense itself. Creating a comprehensive system of juvenile justice will strengthen the stability of society and protect the rights of minors that is a big goal in the modern world.

\section{Acknowledgments}

The author thanks the anonymous reviewers and editor for their valuable contribution.

\section{Funding}

This research received no specific grant from any funding agency in the public, commercial, or not-for-profit sectors.

\section{Author Contributions}

The entire article was written by Kyrylenko Mariia. 
Kyrylenko, M., (2020)

Juvenile justice: genesis and current state in Ukraine

\section{Disclosure Statement}

The author has not any competing financial, professional, or personal interests from other parties.

\section{References}

1. Bready, J., (2016). Juvenile justice: foreign experience and domestic prospects.

2. Data of the State Statistics Service of Ukraine // Correspondent. -2020. - p. 19.

3. Convention on the Rights of the Child: ratified by the Resolution of the Verkhovna Rada of Ukraine № 789XII of February 27, 1991, // Collection of current international treaties of Ukraine. - 1990. - № 1. - P. 205.

4. Constitution of Ukraine [Electronic resource]. - Access mode: http://zakon2.rada.gov.ua/laws/show/254\%D0\%BA/96-\%D0\%B2\%D1\%80.

5. Denisenko, L.V., Dzyubiy, O.A. (2011). Human rights of children: a guide for teachers and trainers K: Printing Time, (2011) - $260 \mathrm{p}$.

6. European Convention on the Exercise of Children's Rights dated 25 January 1996 [Electronic resource]. - Access mode: http:// https://rm.coe.int/168007cdaf.

7. Farafonova, T.V., Views of foreign scientists on the problem of deviations in the behavior of minors, p. 38 .

8. Karpenko, M.I., Boyko, L.I., (2013) The concept of criminal justice for minors in Ukraine, the journal "Legal Science" № 6, (2013).

9. Koteleychuk, S.P. (2018). Theoretical and legal problems of the legal status of minors in Ukraine and ensuring its implementation as one of the main activities of the police: Science: // Theory and history of state and law; history of political and legal doctrines. - K., 2018. - p. 19.

10. Notification of the Ministry of Health of Ukraine № 04.04.4217 / 454. (2020).

11. Smagin, I.I., Areshonkov, V.Yu., Smagina, T.M. (2017). Social and legal protection of childhood Zh.: OIPPO, (2017). - 376 p. 